\title{
The Impact of Sanctions against North Korea on Humanitarian Aid
}

\author{
Nazanin Zadeh-Cummings \\ Centre for Humanitarian Leadership (a Deakin University/Save the Children Partnership); nazanin@deakin.edu.au
}

Lauren Harris

Centre for Humanitarian Leadership (a Deakin University/Save the Children Partnership); lauren.harris@savethechildren.org.au

\begin{abstract}
The Democratic People's Republic of Korea (DPRK, or North Korea) has been a recipient of international humanitarian aid from international organisations (IOs) and non-governmental organisations (NGOs) since 1995. In recent years, multilateral and unilateral sanctions in response to the DPRK's nuclear programme have created a new layer of difficulty for humanitarians looking to engage with the authoritarian state. This paper explores how sanctions are affecting humanitarian work in practice, utilising interviews with practitioners. The research first surveys documentation, particularly from IOs, to establish how humanitarians understand contemporary need inside the country. Next, this paper examines the impacts of sanctions on aid efforts, with a particular focus on multilateral United Nations Security Council (UNSC) sanctions and unilateral American measures. Unpacking humanitarian challenges and potential ways to navigate the sanctions regime provides a foundation for academics and humanitarian practitioners to better understand both the DPRK and possible avenues for principled, effective aid.
\end{abstract}

Keywords: sanctions, North Korea, access, protracted crisis

\section{Introduction}

The Democratic People's Republic of Korea (DPRK, or North Korea) is well known in the media and amongst policymakers in relation to its cult of personality surrounding the Kim family, abuses of human rights, and nuclear weapons programme. In recent years, the DPRK's relationship with the United States and the Republic of Korea (ROK, or South Korea) has seen both flickers of engagement and periods of increased animosity. In 2017, US President Donald Trump was threatening the DPRK with 'fire and fury', but less than a year later met with North Korean leader Kim Jong Un in Singapore. In 2019, Trump and Kim met again in Hanoi, and with ROK President Moon Jae-in at the Demilitarised Zone (DMZ), but these summits and meetings have not resulted in significant, concrete changes to the situation on the Korean peninsula. Moon met with Kim three times in 2018, resulting in increased inter-Korean cooperation including in the areas of sport, management of the DMZ, and transport. In 2019, Seoul channelled US\$10 million in funding for humanitarian aid through UN bodies, including US $\$ 5.5$ million to the World Food Programme (WFP). However, the MoonKim summits have not brought the resumption of previous inter-Korean activities such as increased ability for humanitarian aid from South Korean civil society. ${ }^{1}$

While much of the focus amongst academics, policymakers and the public alike has centred on the DPRK's nuclear programme, humanitarian and human rights issues are of vital importance to the 25 million people living inside the country. The regime's controls on information, movement and access to the outside world hinder knowledge on the humanitarian situation for average and/or vulnerable North Koreans, but data from agencies working inside the country indicates that a prolonged situation of food insecurity and inadequate access to quality healthcare and hygiene facilities persists. $^{2}$

The international humanitarian system in the DPRK includes non-governmental organisations (NGOs), international organisations (IOs) and bilateral organisations. There is no known independent civil society in the DPRK. Humanitarians work with various national and 
local bodies to deliver their programmes. Humanitarian agencies began working in the country in the mid 1990s, after an appeal for international aid due to famine. Levels of aid engagement have fluctuated and the famine ended nearly two decades ago, but humanitarian presence has endured. Some agencies and NGOs have been in the country for over twenty years. Others have ended their projects due to funding, concerns over aid being able to reach the most vulnerable and issues with monitoring (Smith, 2002; Médecins Sans Frontières, 2014), as well as expulsion by the DPRK authorities (Ojardias, 2013: 612). South Korean NGOs require ROK government approval for aid activities to the DPRK, which has varied depending on the political climate. In recent years, the international humanitarian system has been subject to restrictions in the form of unilateral and United Nations Security Council (UNSC) sanctions. As of 2017, Americans must also apply for US government permission for DPRK travel.

This paper goes beyond the policy of sanctions exemptions and asks how sanctions are affecting humanitarian work in practice. The following subsection reviews the methodology used in the research. A literature review rounds out the introduction. Next, the paper gives an overview of the available data on humanitarian need. The research then examines the impacts of sanctions on aid efforts, drawing from interviews with humanitarian practitioners and others with in-depth knowledge of aid delivery in the DPRK. There are four core areas of impact: the burden of exemptions processes, changing relationships with sanctioning and/or implementing governments, reluctance of third parties to engage with humanitarians active in the DPRK, and threats to long-standing relationships and collaborations with North Korean counterparts. The conclusion discusses the implications of this research through both academic and practitioner lenses.

\section{Methodology}

Primary documents utilised in the study include UN and NGO papers, reports and appeals, North Korean and international media sources, and UNSC documents. It is important to note that data gathered in and/or about the DPRK can be incomplete, sporadic and/or lack transparency. However, there is a significant pool of information to draw upon, and as long as limitations and potential biases of data are understood, primary data can be a useful tool for analysis. Humanitarian data, which is subject to the obstacles of working within a repressive system where information and movement are controlled, gives an understanding of how agencies operating in the country quantify and define needs within the constrained environment.
Humanitarian documentation on the DPRK is not without its challenges - access has been a perennial issue, leading several NGOs to withdraw in the 1990s and 2000s. While restrictions remain and continue to be a major challenge, some indicators suggest aspects of access can and have improved. There are reports of improvements in some areas of access starting from the early 2000s (Smith, 2002: 11; UN Office for the Coordination of Humanitarian Affairs, 2000: 1). The UN Resident Coordinator, in 2019, stated that 'we have made great strides in improving access and monitoring for humanitarian agencies in the DPRK through continued, principled, and robust engagement with the Government' (ReliefWeb, 2019). UN agencies have gained some access to markets (Food and Agriculture Organization [FAO]/WFP, 2011), though this is not consistent (FAO/WFP, 2019), and NGOs are able to work directly with local institutions such as hospitals (interview with Roald Føreland of Evangelisk Orientmisjon, 2019). This is not to suggest that access does not remain an issue and a constraint, nor that access improvement has been a linear and steady process. The DPRK government and the restrictions it imposes continue to be major barriers to aid distribution. Instead, this information is presented to acknowledge the small opportunities that could result in greater understanding of the situation in the DPRK.

Semi-structured interviews with participants that have a range of experience working or attempting to work in the sanctioned environment, or with intimate knowledge of contemporary humanitarian work in the DPRK were conducted from April to July 2019. Eight individuals from eight different agencies were interviewed, as well as a group interview with three staffers from the same organisation. Public interviews and events, such as a June 2019 event at the Washington DC-based Cato Institute, were also analysed for trends and understanding of sanctions impact.

Previous scholarship has highlighted the need for information on humanitarian situations to be available to practitioners and decision-makers in digestible, concise formats (Darcy et al., 2013). The authors also produced a practitioner resource, tailored to an intended audience of policymakers and humanitarian workers. ${ }^{3}$

\section{Literature Review}

Sanctions have yet to achieve their stated goal of denuclearisation. ${ }^{4}$ Studies have argued that while sanctions have limited the DPRK's economic growth potential, they have not prohibited it (Kong, 2018) and that state trading companies have increased their procurement capacities under sanctions (Park and Walsh, 2016). This is demonstrative of the double- 
edged' sword of sanctions that appears in academic discourse. Other examples include the argument that the international sanctions regime restricts the DPRK's ability to integrate into the world economy, but may also inhibit domestic economic reform (Gray and Lee, 2017), and that while US sanctions have restricted DPRK economic growth, it is to the detriment of the North Korean people and their standard of living (Kim, 2014). Scholarship has also posited that authoritarian regimes can pass the costs of coping with sanctions impacts on to their people (Haggard and Noland, 2017: 6), which informs Pyongyang's ability to endure sanctions through repression for average citizens and rewards for the elite (Peksen, 2016).

Past research has considered sanctions against the DPRK from a number of perspectives, including political economy (Frank, 2006; Haggard and Noland, 2010), international trade (Noland, 2009), economic statecraft (Haggard and Noland, 2017), US policy (Stanton et al., 2017) and international relations (Habib, 2016). This study does not aim to evaluate the effectiveness of the sanctions in achieving their intended goals, nor does it strive to analyse geopolitical factors that resulted in the sanctions. Instead, this paper investigates the effect of sanctions on humanitarian actors in their attempts to respond to the humanitarian imperative and the need of North Korean people.

While some research has suggested that the UNSC 1718 Sanctions Committee has taken adequate steps to enable humanitarian aid (Do, 2018), other sources have posited that sanctions are at best restricting aid and at worst contributing to rising humanitarian need. Smith (2019: 1) argues that 'absent sanctions exemptions that would allow for necessary oil-based inputs into the 2019 agricultural production cycle, the logical corollary is an expanded food catastrophe, threatening lives and livelihoods of millions of North Koreans in 2020'.

Cohen (2018) argues that the North Korean government is the core obstacle for humanitarians in the DPRK, not sanctions. It is the responsibility of the DPRK government to provide for its people, and through a combination of political choices and repressive control, the DPRK has engineered a largely man-made (though also environmentally impacted) situation of humanitarian need. However, this does not absolve the organised international community from the humanitarian imperative to respond to suffering wherever it is found, or from ensuring the sanctions regime does not negatively impact aid. As the first point of the Red Cross and NGO Code of Conduct affirms: 'The humanitarian imperative comes first .... As members of the international community, we recognise our obligation to provide humanitarian assistance wherever it is needed' (International Committee of the Red Cross, 1994: 1).

\section{Humanitarian Situation in the DPRK}

The DPRK made its first large-scale appeal for international humanitarian aid in 1995. Prior to this, the country was a habitual recipient of fraternal aid from the Soviet Union, China and Eastern Europe. North Korean founder Kim Il Sung's economy needed aid at first to rebuild after the Korean War, and then to sustain itself. While Kim Il Sung's son and successor Kim Jong Il, and grandson and current leader Kim Jong Un, each developed their own attempts at building the DPRK's economy, significant issues have endured. The importance of fraternal socialist support was made devastatingly clear when the Soviet Union collapsed, and China began requiring hard currency for trade. This was further compounded by issues with the planned economy and natural disasters. Also known as the Arduous March, famine killed an estimated 600,000 to 1 million North Koreans between 1995 and 2000 (Goodkind and West, 2001). Humanitarian organisations have had a continuous presence in the DPRK since 1995, with over 230 groups working in the shared spaces for collaboration where regime and humanitarian interests overlap, e.g. boosting agricultural capacity (ZadehCummings, 2019).

Food security has continued to elude the DPRK. The country has struggled to provide adequate nutrition, healthcare, disaster prevention and recovery, and water, sanitation and hygiene (WASH) facilities for its citizens. The Glossary of Humanitarian Terms (ReliefWeb 2008: 21) defines an emergency as 'a sudden and usually unforeseen event that calls for immediate measures to minimise its adverse consequences'. The long-term, structural backdrop of the DPRK's post-famine humanitarian need is not compatible with understandings of humanitarian emergencies. Instead, there is a situation of protracted humanitarian need underpinned not by armed conflict, as in some other contexts, but by political choices.

The DPRK's Humanitarian Country Team (HCT), comprised of UN and other resident humanitarian agencies, releases an annual 'Needs and Priorities' document. While the data and methodology behind the figures in the document are subject to questions of accuracy, the document provides insight into how the humanitarian community working in the country understand need. The latest version at the time of submission, a provisional 2020 document, outlines the sectoral needs (Table 1 ).

A major challenge in responding to humanitarian need is dealing with the political and economic root causes. Decades of choices made by the regime, such as resistance to integration into the global economy and the channelling of resources into the military and the nuclear 
Table 1 Summary of the HCT's 'Needs and Priorities', 2020

\begin{tabular}{|c|c|c|c|}
\hline Sector & People in need & $\begin{array}{l}\text { People targeted } \\
\text { by HCT }\end{array}$ & Sector objectives \\
\hline $\begin{array}{l}\text { Food security } \\
\text { and agriculture }\end{array}$ & 10.1 million & 1.3 million & $\begin{array}{l}\text { 1. 'Increase availability of food and improve nutrition for the population by } \\
\text { increasing the production of staples and other food products using sustainable } \\
\text { production practices.' } \\
\text { 2. 'Increase resilience of vulnerable communities, farmers and cooperative farms to } \\
\text { the impacts of recurrent natural disasters and climate change.' }\end{array}$ \\
\hline Nutrition & 10.4 million & 2.0 million & $\begin{array}{l}\text { 1. 'Support equitable access to quality preventive and curative nutrition services } \\
\text { among under-five children and women of childbearing age.' } \\
\text { 2. 'Support equitable access to nutritious, safe and sufficient food and } \\
\text { micronutrients for vulnerable groups: under-seven children, pregnant women, } \\
\text { lactating mothers and TB patients.' }\end{array}$ \\
\hline $\begin{array}{l}\text { WASH } \\
\text { (water, sanitation } \\
\text { and hygiene) }\end{array}$ & 8.4 million & 307,000 & $\begin{array}{l}\text { 1. 'Improve equitable access to at least basic and safely managed drinking water } \\
\text { and sanitation services.' } \\
\text { 2. 'Raise awareness on public health risks related to water, sanitation and hygiene } \\
\text { and promote adequate and equitable hygiene practices at households, education } \\
\text { institutions and health facilities paying special attention to the needs of women } \\
\text { and girls and those in vulnerable situations.' } \\
\text { 3. 'Strengthen health emergency preparedness and response capacity.' }\end{array}$ \\
\hline Health & 8.7 million & 5.5 million & $\begin{array}{l}\text { 1. 'Contribute to sustained and equitable universal health coverage with emphasis } \\
\text { on essential health services.' } \\
\text { 2. 'Support enhanced quality health services to diagnose and treat communicable } \\
\text { and non-communicable diseases, maternal and childhood diseases and services.' }\end{array}$ \\
\hline
\end{tabular}

Source: Humanitarian Country Team (2020: 4-5).

programme, underpin the DPRK's inability to provide for its population. The humanitarian community is unable to offer solutions that directly address the structural drivers of need. For example, documents and statements from humanitarian agencies cite environmental factors, such as mountainous terrain, a lack of arable land and dry conditions, and insufficient agricultural inputs and infrastructure as the key reasons for the DPRK's food shortages (FAO, 2019; Froberg, 2018; WFP, 2018). However, these explanations do not account for why the DPRK is unable to purchase agricultural inputs itself or address the systemic core of the problem.

\section{Sanctions}

Since the DPRK's first nuclear test in 2006, the UNSC has passed resolutions denouncing the North Korean nuclear programme and sanctioning various aspects of the economy. Though other UNSC resolutions (UNSCRs) have components that relate to humanitarianism, such as UNSCR 2094 in 2013 that called on the DPRK to respond to 'humanitarian concerns of the international community' and stated that resolutions 'are not intended to have adverse humanitarian consequences for the civilian population of the DPRK', it was UNSCR 2397 in 2017 that established humanitarian exemptions. ${ }^{5}$ Unilateral sanctions, namely from the United States, have also had a notable impact on the humanitarian sector. US organisations may need to navigate the Office of Foreign Asset Control (OFAC, part of the US Treasury) and Bureau of Industry and Security
(BIS, part of US Department of Commerce) licenses, as well as restrictions on travel. Since 2017, American citizens must apply for one-time use special validation passports (SVPs) to visit the DPRK. While other unilateral sanctions exist, this paper primarily focuses its exploration of unilateral sanctions on the United States for three reasons. First, there are a notable number of American NGOs working in the DPRK. Second, US restrictions are unique in their inclusion of travel constraints. Third, US secondary sanctions, which target entities and activities outside of American jurisdiction, mean American sanctions have impacts beyond US organisations.

The question this research seeks to answer is on how sanctions impact humanitarian efforts. It is not focused on the direct humanitarian impact of sanctions on the North Korean people. A report published by advocacy campaign Korea Peace Now (2019) estimates that 3,968 preventable North Korean deaths occurred due to sanctions delays and lack of funding. The figure is derived from analysis of proposed UN agency programming that could not go forward due to delays and funding, but rests on several assumptions including on agency capacity and, though not made explicit in the report, on death rates being comparable to other countries (see calculations in Kim and Park, 2019a, 2019b). This figure thus provides a ballpark estimate from one perspective, but methodological challenges and the root causes of need make it difficult to accurately explore and capture the impact of sanctions on humanitarian need on the ground. Hence, this paper instead turns its attention to the organisations attempting to reach the North Korean people. 
This section outlines the impact sanctions have had on humanitarian work through four lenses: (i) the exemptions process, (ii) dealings with third parties, (iii) interactions with sanctioning and/or implementing governments, and (iv) opportunities for humanitarian collaboration with North Korean counterparts. The exemptions process covers aspects of actually applying for sanctions or, in the case of US citizens, travel exemption. Dealings with third parties considers business with entities like banks and suppliers. Interactions with sanctioning and/or implementing governments covers relationships and exchanges involving humanitarian organisations and government entities outside the DPRK. Opportunities for humanitarian collaboration with North Korean counterparts looks at how sanctions have impacted humanitarians' actual and perceived capacity to work with their North Korean interlocutors. Information is drawn from interviews, and where noted, public sources.

\section{Exemptions Process}

Three major areas for exemptions processes came up in interviews: UNSC sanctions, US sanctions and US travel ban. Some non-American groups also discussed restrictions from their countries of origin. Specific difficulties for the different types of exemptions came up, but an overarching theme of increased resources emerged. These include financial resources, human resources and time.

Prior to 2017, American NGOs operated under a General License from the Treasury Department. Under this system, humanitarians did not need to apply for permission if their activities fell within stipulated guidelines. The guidelines have shrunk to cover strictly food and medicine, and NGOs now need to go through the Special License process which can require lawyers and months of processing time (Daniel Jasper of American Friends Service Committee [AFSC] in Cato, 2019). Licenses are granted by OFAC. One area of confusion is around OFAC's use of the term 'partnership'. The OFAC website was updated in March 2018 to state: 'Partnerships and partnership agreements between NGOs and the Government of North Korea or other blocked persons that are necessary for NGOs to provide authorized services are not permitted without a specific license from OFAC.' However, as several interviewees pointed out, the nature of the DPRK means all NGOs must work with government bodies of some capacity.

There was also confusion surrounding UNSC applications, particularly when the sanctions were fairly new. Organisations were unsure whether to list all the items they wanted to bring to the DPRK or only sanctioned items, with different groups taking different approaches (anonymous interview, 2019). Areas of confusion related to UNSC exemptions that came up in interviews included the presence of instructions but a lack of clarity around how things worked in practice, and difficult and opaque bureaucracy. Not all interviewees agreed with this, with one American interviewee finding the UN process clearer than the US process and containing better feedback. American interviewees described different tactics to the process, either choosing to go through the OFAC process first and UNSC exemption second or vice versa. Tracking the outcome of other organisations' exemption processes emerged as a useful tool, with interviewees explaining that they knew to apply for exemptions for certain materials due to the experiences of other humanitarian groups.

The administrative burden was a common theme in interviews. Concerns ranged from time spent on applications and money for lawyers, to a lack of clarity in the various processes. The ability of small organisations to absorb the administrative duties of sanctions applications was a concern to several interviewees. One example of an administrative hurdle came from an interviewee who was applying for an exemption from her home country of Australia. One of her Korean contacts named on the application had a similar - though not identical name to that of an individual sanctioned by the $\mathrm{UN}$. The system flagged this, and the interviewee needed to prove that her contact was not the person under sanctions. She was able to do so by obtaining a passport scan from her partner organisation, but explained that North Koreans may not always be willing to give out such information.

Time was a major concern for interviewees and humanitarians who have spoken about sanctions exemptions - not only time spent on applications, but unreliable processing times. Daniel Jasper explained that AFSC would usually be willing to ship materials like plastic sheeting very quickly to respond to report of agricultural issues, but are now not able to do so (Cato, 2019). This demonstrates that even low-tech, simple responses like providing plastic materials for agriculture are subject to long waiting times, reducing humanitarian ability to respond to need in a timely fashion. The UN Country team reported 22 examples of delays to the UN Panel of Experts (PoE) in January 2019, with some activities being delayed by over nine months (UN PoE, 2019: 364-69).

One interviewee explained that long processing times leave their organisation unable to be flexible and challenges their ability to serve the North Korean people because they need to plan about two and a half years in advance. OFAC licenses can take over a year, according to one interviewee whose license took nearly 250 days. Processes compound - NGOs could need OFAC and BIS licenses, $\mathrm{UN}$ exemptions and US travel permission. Ignis Community, an American NGO, reported that it took 
three years to receive all the necessary permissions for it to resume medical work in the DPRK (Korea Peace Now, 2019: 29).

\section{Third Parties}

US secondary sanctions, or sanctions targeting entities and activities outside the jurisdiction of the sanctioning body, have fostered an environment where banks have very low levels of acceptable risk. This has translated into difficulties with banking and financial transactions for humanitarians, even when all activities are properly exempted and wholly legal. As explained by Heidi Linton of Christian Friends of Korea (CFK), 'the banking channel is largely closed down, so even while it's legal, it's still impossible' (Cato, 2019). Previous banking options that were available to some humanitarians are no longer viable - from 2016-17, UN agencies used a Russian intermediary bank, Bank Sputnik, that was cleared for transactions with the otherwise sanctioned North Korean Foreign Trade Bank for their DPRK work. The channel collapsed in 2017 and no replacement has been put in place.

The key banking issue raised by interviewees was blocked transfers. Another theme was having to carry large amounts of cash into the country, which has been echoed in other sources (Rohrlich, 2018). The impact of secondary sanctions was made clear in spring 2019, when Finnish NGO Fida withdrew from the DPRK after nearly twenty years of engagement in the agriculture and health sectors. Fida's announcement of the decision named OFAC sanctions as one of the problems (UPI, 2019). While Fida is not an American group, the secondary sanctions had extended to impact banks outside the United States. One interviewee explained that the risk tolerance threshold banks have drawn for themselves is much higher than the actual legal threshold. Suppliers have also been wary of working with organisations engaged in the DPRK, as discussed publicly (Fisler, 2018; Linton in Cato, 2019) and in the interviews. An interviewee noted rising costs, as suppliers may raise their fees due to the extra work even exempted activity will bring them.

\section{Sanctioning and/or Implementing Governments}

The range of items that humanitarians have reported to be held up in customs is vast - nutritional sprinkles (Jasper in Cato, 2019), nail clippers (Pennington, 2018) and scalpels (anonymous interview, 2019). Even with proper exemptions, humanitarians face challenges in successfully clearing Chinese customs (anonymous interview, 2019). One interviewee noted that the Chinese border is in fact quite porous - if one is willing to do things below the legal threshold. The interviewee emphasised that their organisation was not open to this and thus were stuck with the challenges of navigating Chinese customs. Another interviewee summarised that China holds a key role in determining the degree to which sanctions are enforced in practice, so Chinese decisions on implementation can have a major impact on humanitarians.

Political influence on humanitarian exemptions has been clearly demonstrated by the United States. In 2019, the US administration decided to issue more SVPs and the US mission to the UN started accepting more UNSC exemptions after essentially putting a hold on them before January 2019 (interview with Daniel Wertz of National Committee on North Korea [NCNK], 2019). The 1718 Sanctions Committee website posted two exemptions notifications from October to December 2018. By contrast, ten exemptions were approved with a start date in January 2019.

While advocacy aimed at changing North Korean government behaviour or raising awareness of human rights violations has been and remains largely a taboo area for organisations with active involvement inside the country, humanitarians have been targeting advocacy efforts at their home governments. One interviewee explained that she had previously had the attitude that she was not engaged in any illicit activities, so why should she have to work harder to prove that she was not doing anything wrong. However, after seeing other groups engage in advocacy towards their home governments in regard to sanctions, the interviewee began opening channels for communication with her home government. She explained that advocating for herself and for her work in the DPRK was now an approach she valued. Other interviewees expressed positive outcomes of advocacy from American NGOs, including the continuation of SVPs (interview with Keith Luse of NCNK, 2019) and the US shift towards more sanctions exemptions in January 2019 (anonymous interview, 2019).

\section{Opportunities for Humanitarian Collaboration with North Korean Counterparts}

Sanctions have the capacity to impact a range of humanitarian sectors, most obviously those requiring parts and machinery. Water and sanitation are key examples, with development of functioning wells facing problems due to metal parts and water filters also being difficult to bring into the country (anonymous interviews, 2019; Jasper in Cato, 2019). Health-related items that have been delayed due to the sanctions exemptions process include reproductive health kits, heaters for immunisation clinics, ambulance parts, refrigerators, wheelchairs, crutches, walking sticks and walkers, glasses and hearing aids; food security programmes have seen delivery of irrigation and agricultural 
equipment that is time-sensitive due to food production seasons postponed in exemptions (UN PoE, 2019: 36469). One interviewee expressed the view that projects have become simpler and are undertaken in areas more conducive to working under sanctions. There are other reasons for using low-tech projects, i.e. concerns over fungibility, difficulty of accessing replacement parts and costs. However, interviewees reported challenges in moving even items that are theoretically outside the reach of sanctions, like medicines, and simple items, like seeds. Long-term knowledge transfer projects, where North Koreans live abroad for an extended period of time and receive a stipend or salary during their training, have become complicated due to restrictions on overseas workers (anonymous interview, 2019).

Sanctions and other constraints appear to be negatively impacting humanitarian ability to gain access and conduct monitoring activities - two aspects of aid work that have been a focus of humanitarians and those against providing assistance to the DPRK alike. One interviewee explained that NGOs have increased opportunities for access, but are unable to harness these opportunities due to challenges of sanctions and securing funding (interview with Esther Im of NCNK, 2019). Funding has an impact on access and monitoring in that humanitarians need adequate resources to expand their programmes, as well as to justify requests to the DPRK authorities for access to new areas. However, humanitarian funding for the DPRK has struggled - annual appeals from the HCT 2015 and 2019 averaged to achieve only $27.3 \%$ of requested funding. This is not a direct result of sanctions, which for example do not prohibit donor states from contributing to humanitarian appeals for the DPRK, but one that compounds the numerous barriers to aid delivery.

The more direct impact of sanctions on access and monitoring can be understood in two ways: through relationships and through physical ability for aid and people to reach the DPRK. First, trust is a key component to successful aid projects in the DPRK, but the sanctions environment threatens to erode trust and increased potential for access by restricting activities and in the case of Americans, travel. One interviewee worried that while NGOs were trying to counter the enemy image of Americans cultivated by the DPRK, the sanctions were reinforcing it. Second, multiple interviewees spoke about monitoring - one mentioned that they were planning a monitoring trip, but this was dependent on exemptions coming through in time because otherwise there would be nothing to monitor. Another had been in the situation where the United States approved shipments, but denied SVP requests. This meant the monitoring team was not able to travel. The organisation was able to send nonAmericans instead of the US citizen staff that typically went on monitoring trips that may have had more suitable expertise to conduct the monitoring trip.

Several interviewees explained that other organisations are interested in engaging in DPRK work, but the sanctions deter them from doing so. While obstacles are significant, humanitarians have persisted. In 2019, thirty-eight UNSC humanitarian exemptions were granted to fourteen NGOs, three UN agencies, the IFRC and the International Committee of the Red Cross (ICRC), the Swiss Agency for Development and Cooperation, and two Italian entities.

\section{Conclusion}

Amongst the backdrop of nuclear tests and political fluctuations, humanitarians are facing greater challenges in responding to needs - and perhaps in learning about unknown needs - due to sanctions. Sanctions, with a focus in this paper on those from the UNSC and from the United States, have exemptions to allow humanitarian work to continue. Yet aid organisations still face obstacles to delivering timely and effective aid. Interviews and publicly available statements from humanitarians revealed four key areas of impact. First, the exemptions process itself brings a resource burden, including time, money and human resources. Second, third parties, namely banks and suppliers, have a low risk threshold and will often choose not to work with organisations engaged in the DPRK even in exempted, legal situations. Third, advocacy aimed at implementing and sanctioning governments is seen as a potential avenue for progress. Fourth, the sanctions may roll back progress from years of trust building and relationships with North Korean counterparts, and also discourage organisations from working in the DPRK.

While humanitarian exemptions are present in sanctions legislation and many organisations are finding ways to continue their work, it is clear that building sustainable and effective programmes to respond to humanitarian need is being challenged by bureaucratic processes. Humanitarian response in the DPRK faced a number of obstacles before the sanctions, most notably restrictions put in place by the North Korean government but also in securing adequate funding. Sanctions in their current form add an additional layer of challenge to an already strenuous context. A clear understanding of the nature of humanitarian work, including the crosscutting impact of sectors and the need for holistic responses, is needed for all stakeholders to ensure that legitimate humanitarian efforts are not hampered. For example, tackling tuberculosis goes beyond shipping medicine - adequate water and sanitation, proper nutrition, pharmaceuticals and medical care are all required for effective response. 
Tackling risk perception amongst banks and suppliers is difficult, as private companies do not have incentive to increase their resource burden to better understand humanitarian exemptions. The compound nature of exemptions - for example, an American NGO may need OFAC, BIS, UN and SVP permissions - challenges the ability of humanitarian aid to be responsive, agile and timely. As long as the sanctions regime is in place, sanctioning governments and bodies must consider the realities of the processes and their impact on humanitarian aid for the North Korean people.

\section{Acknowledgements}

We extend our deep gratitude to our interviewees. We would also like to extend special thanks to Melanie Book at the Centre for Humanitarian Leadership for valued comments and input to this project.

\section{Notes}

1 South Korean sanctions, known as the May 24 measures, have prohibited organisations from delivering inter-Korean humanitarian aid without Seoul's approval since 2010. In 2018, South Korean Foreign Minister Kang Kyung-wha raised the possibility of revisiting the measures. The Foreign Ministry later clarified that there was no government-wide review of the measures, and they continue to remain in place.

2 An example, though by no means the only source, of such data is the DPRK Humanitarian Country Team's annual 'Needs and Priorities' document.

3 See Zadeh-Cummings and Harris (2020).

4 The DPRK, the United States and other major players do not share a consensus on the meaning of denuclearisation, leaving varying interpretations of the word. What is clear is that substantive nuclear talks have not restarted, never mind meaningfully progressed, at the time of submission.

5 [The Security Council] 'decides that the Committee may, on a case-by-case basis, exempt any activity from the measures imposed by these resolutions if the committee determines that such an exemption is necessary to facilitate the work of such organisations in the DPRK or for any other purpose consistent with the objectives of these resolutions' (para. 25, emphasis in original).

\section{Bibliography}

Cato Institute (2019, 11 June), 'Peering Beyond the DMZ: Understanding North Korea behind the Headlines' [video], www.cato.org/ events/peering-beyond-the-dmz (accessed 31 October 2019).

Cohen, R. (2018), 'Sanctions Hurt but Are Not the Main Impediment to Humanitarian Operations in North Korea', Asia Policy, 25:3, 35-41.

Darcy, J., Stobaugh, H., Walker, P. and Maxwell, D. (2013), The Use of Evidence in Humanitarian Decision Making: ACAPS Operational Learning Paper (Somerville, MA: Feinstein International Center).
Do, K. (2018), Sanctions against North Korea and Humanitarian Exemptions, Korea Institute for National Unification Online Series 18-37. repo. kinu.or.kr/handle/2015.oak/9461 (accessed 31 October 2019).

Fisler, T. (2018), 'How International Agencies in North Korea Get Things Done', interview by Jacco Zwetsloot for NK News Podcast (19 November), episode 46. www.nknews.org/2018/11/how-internationalagencies-in-north-korea-get-things-done-nk-news-podcast-ep-46/ (accessed 31 October 2019).

Food and Agriculture Organization (2019), Early Warning Early Action Report on Food Security and Agriculture, (Rome).

Food and Agriculture Organization/World Food Programme (2011), FAO/WFP Crop and Food Security Assessment Mission to the Democratic People's Republic of Korea, (Rome).

Food and Agriculture Organization/World Food Programme (2019), Democratic People's Republic of Korea (DPRK): FAO/WFP Joint Rapid Food Security Assessment, (Bangkok).

Frank, R. (2006), 'The Political Economy of Sanctions against North Korea', Asian Perspective, 30:3, 5-36.

Froberg, M. (2018), 'Cultivating Hope in DPR Korea', International Federation of Red Cross and Red Crescent Societies, https://reliefweb. int/report/democratic-peoples-republic-korea/cultivating-hope-dprkorea (accessed 31 October 2019).

Goodkind, D. and West, L. (2001), 'The North Korean Famine and Its Demographic Impact', Population and Development Review, 27:2, 219-38.

Gray, K. and Lee, J-W. (2017), 'Following in China's Footsteps? The Political Economy of North Korean Reform', The Pacific Review, 30:1, 51-73.

Habib, B. (2016), 'The Enforcement Problem in Resolution 2094 and the United Nations Security Council Sanctions Regime: Sanctioning North Korea', Australian Journal of International Affairs, 70:1, 50-68.

Haggard, S. and Noland, M. (2010), 'Sanctioning North Korea: The Political Economy of Denuclearization and Proliferation', Asian Survey, 50:3, 539-68.

Haggard, S. and Noland, M. (2017), Hard Target: Sanctions, Inducements, and the Case of North Korea (Stanford, CA: Stanford University Press).

Humanitarian Country Team (2020), Provisional Needs and Priorities DPR Korea, https://reliefweb.int/sites/reliefweb.int/files/resources/2020_ DPRK_N\%26P_Overview_Provisional.pdf (accessed 6 August 2020).

International Committee of the Red Cross (1994), Code of Conduct for the International Red Cross and Red Crescent Movement and NonGovernmental Organizations (NGOs) in Disaster Relief, (Geneva).

Kim, H. (2014), 'Stifled Growth and Added Suffering: Tensions Inherent in Sanctions Policies against North Korea', Critical Asian Studies, 46:1, 91-112.

Kim, J. and Park, K. B. (2019a), 'Water, Sanitation, and Hygiene: Can North Korea Be WASHed Free of Disease?', The Diplomat (2 August).

Kim, J., and Park, K. B. (2019b), 'How Sanctions Hurt North Korea's Children', Global Health Now (5 August).

Kong, T. Y. (2018), 'The Advance of Marketization in North Korea: Between Political Rigidity and Economic Flexibility', Modern Asian Studies, first published online 2 November 2018, doi: 10.1017/ S0026749X18000550

Korea Peace Now (2019), The Human Costs and Gendered Impact of Sanctions on North Korea, https://koreapeacenow.org/wp-content/uploads/2019/ 10/human-costs-and-gendered-impact-of-sanctions-on-northkorea.pdf?mod=article_inline (accessed 31 October 2019).

Médecins Sans Frontières (2014), MSF and North Korea: 1995-1998, www. msf.org/sites/msf.org/files/2019-04/MSF\%20Speaking\%20Out\% 20North\%20Korea\%201995-1998_0.pdf (accessed 31 October 2019).

Noland, M. (2009), 'The (Non-) Impact of UN Sanctions on North Korea', Asia Policy, 7, 61-88. 
Ojardias, F. (2013), 'Le dilemma humanitaire en Corée du Nord: l'expérience des ONG européennes [The Humanitarian Dilemma in North Korea: The European NGO Experience]' (PhD dissertation, Institut national des langues et civilisations orientales [National Institute for Oriental Languages and Civilisations]).

Park, J. and Walsh, J. (2016), Stopping North Korea, Inc: Sanctions Effectiveness and Unintended Consequences (Cambridge, MA: MIT Security Studies Program).

Peksen, D. (2016), Authoritarian Regimes and Economic Sanctions Effectiveness: The Case of North Korea, Academic Paper Series - On Korea (Washington, DC: Korea Economic Institute of America).

Pennington, M. (2018), 'Charities See Nail Clippers, Shovels are North Korean No-Nos', AP News (28 January).

ReliefWeb (2008), Glossary of Humanitarian Terms, https://reliefweb.int/sites/reliefweb.int/files/resources/4F99A3C28EC37D0EC12574A4002E89B4-reliefweb_aug2008.pdf (accessed 31 October 2019).

ReliefWeb (2019), 'Statement by Mr. Tapan Mishra, UN Resident Coordinator in DPRK, on the release of the 2019 Needs and Priorities Plan' (6 March), https://reliefweb.int/report/democraticpeoples-republic-korea/statement-mr-tapan-mishra-un-resident-coordinator-dprk (accessed 31 October 2019).

Rohrlich, J. (2018), 'How NGOs in North Korea Continue to Face Major Sanctions-Related Hurdles', NK News (27 June).

Smith, H. (2002), Overcoming Humanitarian Dilemmas in the DPRK (North Korea), Special Report 90 (Washington, DC: United States Institute of Peace).
Smith, H. (2019), 'North Korea’s Year of Reckoning: Famine, Sanctions and Security', Pacific Forum, PacNet 20 (6 March).

Stanton, J., Lee, S-Y. and Klingner, B. (2017), 'Getting Tough on North Korea: How to Hit Pyongyang Where It Hurts', Foreign Affairs, 96:3, 65-75.

United Nations Office for the Coordination of Humanitarian Affairs (2000), Consolidated Inter-Agency Appeal for Democratic People's Republic of Korea, Mid-Term Review, https://reliefweb.int/sites/reliefweb.int/files/resources/DPRK\% 20FINAL\%20MTR\%2016\%20JULY\%202000.pdf (accessed 31 October 2019).

United Nations Panel of Experts (2019), Report of the Panel of Experts established pursuant to resolution 1874 (2009), https://undocs.org/S/ 2019/171 (accessed 31 October 2019).

UPI (2019), 'Finnish NGO Quits Operations in North Korea amid Sanctions' (23 June).

World Food Programme (2018), 'WFP DPR Korea Country Brief: October 2018', https://reliefweb.int/sites/reliefweb.int/files/ resources/WFP-0000100473.pdf (accessed 31 October 2019).

Zadeh-Cummings, N. (2019), 'Humanitarians in the Hermit Kingdom: Aid, Access, and NGOs in the DPRK' (PhD dissertation, City University of Hong Kong).

Zadeh-Cummings, N. and Harris, L. (2020), 'Humanitarian Aid in North Korea: Needs, Sanctions, and Future Challenges', Centre for Humanitarian Leadership, https://centreforhumanitarianleadership. org/wp-content/uploads/2020/04/CHL_North-Korea-Report_Final. pdf (accessed 6 August 2020). 